\title{
Poverty Incidence in Nigeria: The Centrality of Sustainable Natural Resource Management
}

\author{
Corresponding author's name: Fisayo Fagbemi \\ Independent Researcher, Nigeria \\ ORCID iD: Fisayo Fagbemi https://orcid.org/0000-0002-5742-1514 \\ E-mail: fisay4real@yahoo.com
}

\author{
Co-author's name: Kehinde Mary Bello \\ Graduate Student of the Department of Economics, Obafemi Awolowo University, Ile-Ife, Nigeria \\ E-mail: kennybello2008@gmail.com \\ Coauthor's name: Omowumi Grace Adeoye \\ Graduate Student of the Department of Economics, Obafemi Awolowo University, Ile - Ife, Nigeria \\ E-mail: adeoyegrace2@gmail.com
}

\begin{abstract}
This study explores the relationship between resource rents and poverty incidence in Nigeria based on annual time series data between 1984 and 2016. The analysis is conducted with the use of Dynamic Least Squares (DOLS), Fully Modified Least Squares (FMOLS) and Canonical Cointegrating Regression (CCR), while the causal link is examined using Vector Error Correction Model (VECM) approach. With the particular emphasis on long-term effect, the study unravels the full potential of resource rents for lasting poverty reduction. Empirical findings establish that there is a long-term adverse and significant relationship between resource rents and poverty headcount, although increased resource rents could only lead to a substantial reduction in the number of poor people, if windfall revenues from natural resources are channeled towards pro-poor investments. Further evidence reveals that the effect of non-oil rents is more profound in reducing poverty compared with oil rents, suggesting that according considerable attention to non-oil sector other than oil sector could enhance poverty alleviation. Results also indicate that there is bi-directional causal relationship between poverty and oil rents and total natural resource rents, whereas for non-oil rents, it is unidirectional running from non-oil rents to poverty. Hence, the study suggests that strengthening the quality of governance for the enhancement of pro-poor investment strategies and effective management of natural resource windfalls is central for alleviating poverty in Nigeria.
\end{abstract}

Key words: Poverty incidence, natural resource rents, resource management, cointegration analysis, Nigeria.

\section{Introduction}

The mainstream development policy has firmly established that resource-poverty linkage is essential for the enhancement of development outcomes. In developing countries, the poor are particularly dependent on "common property" natural resources and ecosystem services for a means of living. Much of the extensive debate over sustainable livelihood approach in the last decade has veritably turned around the question about poverty and natural resource dimension. A layman's view would be that better access to resources is a good starting point to accentuate improved welfare, as common property natural resources are a significant source of food, fuel, medicinal plants, building materials and income for the rural poor (OECD, 2008). Compared with developed countries, primary production accounts for a much higher share of production, exports, domestic trade and gross national product in developing countries. In these economies, particularly in sub-Saharan Africa, natural resource-based industry thus offers substantial employment and income opportunities. Although, through resource extraction, many states have funded their development, in Africa, this has not been effective. The continent holds higher percentages of the world's natural resources and as much as $30 \%$ of global mineral reserves, yet a significant reduction in sustainable development yield persistently. Over the years, reversing this trajectory has dominated policy debates. 
Sub-Saharan Africa (SSA) is enmeshed in different forms of poverty, given the low level of human capital development in the region (World, 2018). Since Human Development Index (HDI) which encompasses the standard of living dimension is viewed as the ultimate criteria for measuring the development of a country, the pervasive poverty incidence across African countries has given rise to debate about the state of governance quality and government policy priorities. Indeed, the deteriorating state of socio-economic indicators such as low per capita income, poor access to education, safe water, sanitation facilities and health care services is a reflection of the high prevalence of inequality and poverty in the region (Adeyemi, Ijaiya and Raheem, 2009). Hence, major difficult challenges facing SSA countries (in particular Nigeria) are poverty reduction and the greatest impediment to the entrenchment of sustainable management measures. For instance, in Nigeria, despite appealing depiction of natural resource abundance or resource rents (Figure 1), more than two-thirds of her people are poor. It is no longer news that Nigeria is regarded as "the poverty capital of the world" - the country with the highest number of extremely poor people - (Brookings Institution, 2018). This has negated the implicit assumption that every citizen enjoys the proceeds arising from the sales of these resources.

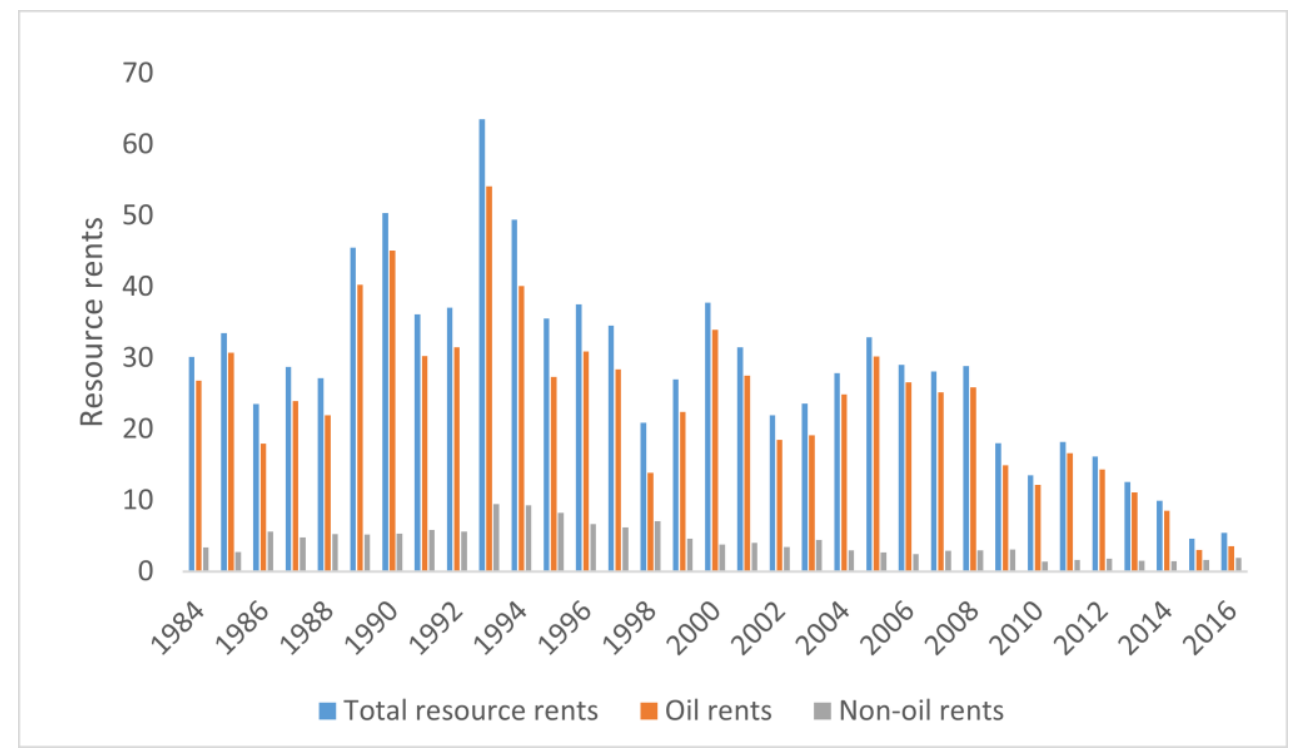

Figure 1. Nigeria - oil rents; non-oil rents; total natural resource rents (\% of GDP) between 1984 and 2016. Source: Authors' estimates based on data from World Development Indicator (WDI), World Bank (2018).

This startling paradox should be given utmost consideration in order to abate the persistence of 'grinding poverty' in resource abundance countries. With sound public management, natural resources can offer the basis for long-term sustainable pro-poor growth (OECD, 2008). Concerns over the sustainable natural resource use are necessitated by the outcome of increasing conventional theoretical divergences between local and global (or among researchers), which have become somewhat redundant in offering an elucidation of the better arrangements through which the means of livelihoods could be best sustained (Mehta et al., 2000). Many policies initiated to tackle the menace of the spiralling incidence of poverty rarely meet their predetermined goals; in short, policy's objective scarcely come to fruition. The uncertainty with which countries exercise their sustainable strategies has increasingly engendered the renewed trend on resource-poverty discourse. For ascertaining the nature of natural resource-poverty linkages, it is essential to articulate ways these could be plausibly established through empirical analysis. Thus, questions as to how best the use of natural resources could ameliorate poverty incidence should be addressed.

This study is exclusively anchored in the imperative to find the plausible ground that could restore the significant nexus between natural resources and poverty alleviation in Nigeria, which has remained controversial in the literature. Specifically, the paper sets to assess the relationship between natural resources and poverty reduction in Nigeria. The rest of the paper is segmented as follows: The next section dwells on the literature review. Section three gives data 
description and methodology. Results and discussion are offered in section four, while sections five contains the concluding remarks.

\section{Literature review}

\subsection{Theoretical expositions on natural resource-poverty nexus}

In the process of ensuring better understanding on several channels through which natural resources influence the development trajectory of any economy, some authors employed different models to assess the mechanisms underlining natural resource-poverty nexus. The nexus between natural resources and poverty is well-pronounced in developing economies, as the welfare state of many households in these economies directly depends on the environmental quality and on the natural resource availability (Ruijs, 2008). According to the literature, the extraction of natural resources could adversely alter a country's development path in various ways: Two of the most commonly identified channels are: the Dutch- disease effects - which stresses that following a contraction of the tradable manufacturing sector, a resource boom leads to overvaluations of the real exchange rates (Torvik, 2001; Atkinson and Hamilton, 2003) - and the volatility of commodity prices, that often stimulate pro-cyclicality of public spending, savings and capital flows. While studying empirically the effect of natural resources on economic performance using worldwide cross country data, Sachs and Warner (1995) attune to the notion that resource-abundant countries often experience negative economic and political outcome compared to resource-poor countries.

Corroborating the argument, due to the interplay between endogenous interest rates and volatile resource returns in imperfect capital markets, Hausman and Rigobon (2002) explain how the tradable manufacturing sector could be negatively affected by lack of investments. Furthermore, a booming resource sector might also discourage entrepreneurship and innovation (Sachs and Warner 2001) or crowd out public and private investments in education, or human capital (Gylfason 2001). Strong primary sectors trigger the disincentives for developing more educationintensive sectors. Hence eroding a country's capacity to compete on world markets, and in the long run, undermining the potential for export-led growth. Given empirical postulations, the low level of human capital development in resource-abundant countries plays a considerable role in the adverse impact of natural resources on growth (Gylfason, 2001). One-dimensional perspective recognizes change and learning systems as essential for improved technology and sustainable development. Policy change is crucial to the creation of enabling environment for ensuring sustainable natural resource use and improved social welfare (Tripp, 2003; Akhtar-Schuster et al., 2011).

Another transmission mechanism is anchored on prevailing rent-seeking behavior. This is built on the premise that in resource-rich countries, a substantial number of agents often engaged in rent-seeking, which induce bribes and inefficient allocation of labor, and policies could also be distorted. The rents generated by natural resources are rendered ineffective by this 'voracity effect'. By and large, there is penchant for unproductive activities, especially by the elite. For instance, a model develops by Torvik (2002) show how resource abundance causes a rise in the payoffs from unproductive rent seeking behavior, and as consequence, retards overall growth of the economy. On the other hand, following Lane and Tornell (1996), in countries with powerful groups and weak institutions, natural resource windfalls inhibit growth rate, as increased productivity offers incentives for the demand for transfers, and these reallocation effects could downplay the growth-enhancing effect of resource endowments. However, some authors suggest that the effect of resources on economic development is not the same in all countries, as they could be a curse to development for some countries and not for others. Most findings on the linkage between resource abundance and growth have been context-specific and basically shaped by "initial conditions" (Acemoglu 1995; Baland and Francois, 2000). The adverse relationship has been tied to certain conditions while adding the institutional context to the analysis (Mehlum et al., 2002; Bulte, Damania and Deacon, 2004). These authors investigate the inter-relationship between natural resources, institutions, and human and economic development. Although limited evidence is find for a direct impact of natural resources on human development, an indirect channel through institutional quality is empirically established. The full benefits of resources are perceived to be materialized via the help of institutions in most countries ${ }^{1}$. Nonetheless, the Dutch disease hypotheses and the rent-seeking advocate an unconditional adverse effect of natural resources on economic growth, which could also retard human development or social welfare (Mehlum, Moene and Torvik, 2006).

\footnotetext{
${ }^{1}$ In contrast, some author argue that the quality of the institutional environment of countries are shaped by natural resources (Leite and Weidmann, 1999; Hodler, 2006; Badinger and Nindl; 2014).
} 


\section{$2.2 \quad$ Empirical evidence}

Attempts to identify the key factors that induce the incidence of poverty in most resource abundant countries have given rise to more controversial issues in recent times. Various empirical studies on natural resource-poverty linkage have demonstrated that natural resources influence the incidence of poverty in resource-rich countries in diverse dimensions (Adams et al., 2004; Sunderlin et al., 2005). Hence, a review of the pathways by which these mixed conclusions developed is systematically assessed in this section. A critical survey of the literature will unravel the framework or measures essential for offering a firm view on how to identify different reasons that exacerbate the spiralling poverty level in most resource-dependent economies.

Given that a substantial number of research work has been centered on the role played by natural resources and institutions in highlighting the growth prospects of countries in light of global settings (Sala-i-Martin and Subramanian, 2003, 2013; Raggl, 2017), some few others focus on the relationship between human capital development (or poverty) and natural resources. For example, Hulme et al. (2001) stress that natural resource management could be significant to strategies to reduce "chronic poverty". Other authors that also argue in favour of this assertion include; Ashley and Maxwell, (2001); Bird et al. (2002). In sharp contrast with most findings, Frankel (2010) demonstrates that natural resources could foster development, and natural resource endowments are not per se a curse, but more of a "double-edged sword". Corroborating this, Pineda and Rodriguez (2010) reveal that exports of natural resources have a positive influence on economic growth (but not very strongly), while positively induce changes in the Human Development Index. However, these authors recognize that the exploitation of natural resources do more harm than good in several countries.

Bulte et al. (2004) assess whether the adverse statistical relationship between natural resource abundance and growth spills over to other significant economic and social indicators, while scrutinizing several proxies of economic underdevelopment and welfare. They posit that underdevelopment and welfare state are clearly dependent on economic growth. Another study conducted by Neumayer (2004) basically centers on whether natural resource endowments adversely affect economic growth. The author established that if growth is measured in terms of GDP less depreciation on capital for real income determination, the natural resource abundance diminishes economic performance. Using a large set of data, Auty (2001a) suggests that per capita GDP of resource-poor economies grows at rates much better than those of resource-rich countries between 1960 and 1990. Raggl, (2017) stresses that accumulation both human and physical capital, but also natural resource rents and institutional quality are estimated to be particularly vital ingredients for enhanced economic development in Nigeria.

Focusing on the significance of sustainable natural resource use, Odularu (2008) using Ordinary Least Square of multiple regression method and the Cobb-Douglas production function to examine the relationship between the crude oil sector and the Nigerian economic performance. The author establish that oil production, capital and labour force can surely result to economic growth, with particular emphasis on the effective management of oil production by the government. Analogously, applying ordinary least square of regression analysis on primary data, Akinwale (2012) assesses the existence of resource curse in Nigeria. Accordingly, Dutch Disease, volatilities of oil price, poor technological advancement, poor democracies, high level of corruption, high level of indebtedness, weak and unaccountable institutions, poor investment in education as well as insurgency in the oil producing region are identified as factors that trigger the existence of resource curse in the country. The study concludes that sustainable management of resources would ameliorate poverty incidence in Nigeria. Furthermore, Manzano and Scrofina (2013) focus on the resource revenue management in Venezuela. Following consumption-based poverty reduction strategy, through different channels (such as the national oil company) indicate that oil windfalls have been mostly appropriated by the government. Authors further show that, in terms of priorities, the main policy thrust of Venezuela government has been to alleviate poverty using the money realized from oil sales, although with mixed results. More importantly, using Vector Auto- Regression (VAR) model and with cumulative impulse-response and variance decomposition analysis, Simon-Oke (2016) examines the influence of petroleum resources on poverty level in Nigeria between 1981 and 2012. Findings reveal that despite the numerous benefits derived from petroleum resources, there is still high rate of poverty. In general, it is evident that the country experienced increasing oil rents with corresponding increase in poverty level. Thus it is suggested that ensuring transparent and judicious use of oil proceeds could induce improved standards of living in the country.

With these preceding expositions, it is more appropriate to get the incentives for enhancing sustainable natural resource management right. As most studies reviewed mainly center on the effect of oil rents on human and economic development, and given the controversial issues that ensue, an all-encompassing study that cover a substantial part of 
the natural resource sector in Nigeria is critical to embracing broad-based sustainable management measures and improved well-being in the country.

\section{Data and methodology}

\subsection{Data}

In attempting to achieve the main objective of the study, annual time series data from 1984 to 2016 are employed. This entails the period of both high and low commodity prices in the global markets. The scope seems sufficient to have holistic coverage of the effect of natural resource sector on poverty incidence. Accordingly, three natural resources indicators comprising non-oil rents (\% of GDP), oil rents (\% of GDP) and total natural resource rents (\% of GDP) are used, while poverty headcount ratio at $\$ 1.90$ a day (2011 PPP) (\% of population) represents the poverty measure. This indicator of poverty has been identified as most appropriate for capturing poverty level in an economy (kale, 2012). As some variables are considered important in natural resource - poverty literature, GDP per capita; democratic accountability and remittances are also included in the model. Given the role of institutions in poverty alleviation measures, the inclusion of democratic accountability is critical to attaining robust findings. In table 1 , detailed definition and description of the data and their respective sources are stated.

Table 1. Variable description and definition

\begin{tabular}{|c|c|c|}
\hline Variable & Description/definition & Source \\
\hline \multicolumn{3}{|l|}{ Dependent Variable } \\
\hline Poverty headcount & $\begin{array}{l}\text { It represents the percentage of the population living on } \\
\text { less than } \$ 1.90 \text { a day at } 2011 \text { international prices }\end{array}$ & $\begin{array}{l}\text { World Development Indicators } \\
\text { (2018 Edition). }\end{array}$ \\
\hline \multicolumn{3}{|l|}{ Explanatory variables } \\
\hline GDP per capita & $\begin{array}{l}\text { It is gross domestic product divided by midyear } \\
\text { population }\end{array}$ & $\begin{array}{l}\text { World Development Indicators } \\
\text { (2018 Edition). }\end{array}$ \\
\hline Remittances & $\begin{array}{l}\text { Consist personal transfers and compensation of } \\
\text { employees. Personal transfers thus include all current } \\
\text { transfers between resident and nonresident individuals. } \\
\text { Compensation of employees refers to the income of } \\
\text { border, seasonal, and other short-term workers who are } \\
\text { employed in an economy where they are not resident and } \\
\text { of residents employed by nonresident entities. }\end{array}$ & $\begin{array}{l}\text { World Development Indicators } \\
\text { (2018 Edition). }\end{array}$ \\
\hline Democratic accountability & $\begin{array}{l}\text { It captures various ways in which political parties, } \\
\text { citizens, parliaments and other democratic actors and } \\
\text { institutions can provide feedback to, reward or sanction } \\
\text { officials in charge of setting and enacting public policy. }\end{array}$ & $\begin{array}{l}\text { International Country Risk } \\
\text { Guide (2018 Edition) }\end{array}$ \\
\hline Oil rents & $\begin{array}{l}\text { Show the difference between the value of crude oil } \\
\text { production at world prices and total costs of production. }\end{array}$ & $\begin{array}{l}\text { World Development Indicators } \\
\text { (2018 Edition). }\end{array}$ \\
\hline Non-oil rents & Natural resource rents excluding oil (\% of GDP) & $\begin{array}{l}\text { World Development Indicators } \\
\text { (2018 Edition). }\end{array}$ \\
\hline Natural resource rents & $\begin{array}{l}\text { Represent the sum of oil rents, natural gas rents, coal } \\
\text { rents (hard and soft), mineral rents, and forest rents. }\end{array}$ & $\begin{array}{l}\text { World Development Indicators } \\
\text { (2018 Edition). }\end{array}$ \\
\hline
\end{tabular}

\subsection{Methodology}

Following the preceding theoretical exposition, the model that simulates the functional relationship between natural resources and poverty is specified as;

$P O V T=f(N A T, D A C C G D P, R E M)$

Where POVT represents poverty indicator. NAT is defined as natural resource variables. Democratic accountability is represented by $D A C C$. Remittances is indicated by REM whereas GDP connotes GDP per capita. The variables are in logarithm form with the exception of democratic accountability.

Basically, this study employs dynamic ordinary least squares (DOLS) technique developed by Stock and Watson (1993). DOLS is a simple approach for constructing the asymptotically efficient estimator which removes the feedback 
in the cointegration model. Based on Stock and Watson (1993), this technique is most appropriate when all variables in the model are I (1) (as they are in this study); otherwise it is inefficient and unreliable. Hence, the technique is modeled in the form as;

$V_{t}=\gamma_{0}+\beta Z+\sum_{J=-n}^{m} \theta \Delta Z_{t-j}+\mu_{t}$

$V_{t}$ indicates poverty headcount ratio (dependent variable). $Z$ represents the matrix of the explanatory variables. $m$ connotes the lag length. $\beta$ is defined as the cointegrating vector, while $n$ is the lead length.

Lag and lead terms are added in order to ensure that stochastic error term in DOLS regression becomes independent of all past innovations in stochastic regressors. For ensuring the robustness of the empirical results both Conical Cointegration Regression (CCR) and Fully Modified Least Squares (FMOLS) are estimated. Moreover, taking spurious regression case into account, the tests of unit roots are also conducted.

Given that error correction representation is present, when the long-run association exists among the estimated variables. According to Akinlo and Akinlo (2009), through the estimated model, the Error Correction term is secured and then, the short-run dynamics is examined with the estimation of the Vector Error Correction Model (VECM). Although it does not show the direction of causality, in at least one direction, the existence of cointegration implies that there is Granger causality (Engle and Granger, 1987). Therefore, the Granger causality test through the VECM framework will reveal the causality direction between natural resources and poverty reduction. VECM model is thus specified as follows;

$$
\begin{gathered}
\begin{aligned}
\Delta \mathrm{POVT}_{t}=\alpha_{0}+ & \sum_{i=1}^{k 1} \delta_{1 i} \Delta P O V T_{t-i}+\sum_{i=0}^{P} \delta_{2 i} \Delta N A T_{t-i}+\sum_{i=0}^{P} \delta_{3 i} \Delta D A C C_{t-i}+\sum_{i=0}^{P} \delta_{4 i} \Delta G D P_{t-i}+\sum_{i=0}^{p} \delta_{5 i} \Delta R E M_{t-i} \\
& +\vartheta_{i} E C T_{t-1}+\mu_{1 t}
\end{aligned} \\
\qquad N A T_{t}=\theta_{0}+\sum_{i=1}^{k 2} \theta_{1 i} \Delta N A T_{t-i}+\sum_{i=0}^{P} \theta_{2 i} \Delta P O V T_{t-i}+\sum_{i=0}^{P} \theta_{3 i} \Delta D A C C_{t-i}+\sum_{i=0}^{P} \theta_{4 i} \Delta G D P_{t-i}+\sum_{i=0}^{p} \theta_{5 i} \Delta R E M_{t-i} \\
\quad+\varphi_{i} E C T_{t-1}+\mu_{1 t}
\end{gathered}
$$

In equation (3) \& (4), ECT captures the speed of adjustment to equilibrium and long-run relationship, whereas $\triangle P O V T_{t-i}, \Delta N A T_{t-i}, \triangle D A C C_{t-i}, \Delta G D P_{t-i}, \Delta R E M_{t-i}$, indicate the short-run dynamics of the model. Theoretically, $(\vartheta \& \varphi)$ of ECT should be negative significant estimates, which indicates that after a shock in the short-run, the negative sign of ECT estimates connotes that the dependent variable adjusts back to its equilibrium value (Akinlo and Akinlo, 2009). This represents the long run causal effect. Notably, the statistical significance of both $(\vartheta \& \varphi)$ estimates implies that there is bi-directional causality between NAT \& POVT. On the other hand, if only one estimate is significantly negative, unidirectional causality is said to exist.

\section{Empirical results and discussion}

The main focus of major existing studies has been on the impact of natural resources on economic growth, and there is prevailing consensus that a case of 'resource curse' is evident in most resource-rich countries. However, this is only a single dimension of human well-being measure, it is intuitively plausible that natural resources could lead to improved welfare when other human development measures are factored in (such as poverty rate, infant mortality, access to education and health services). Thus, the study specifically examines the link between natural resource rents and poverty headcount in Nigeria. The analysis begins with the test of stationarity using Augmented Dickey Fuller (ADF) and Phillips-Perron (PP). Table 2 presents the results of the unit root tests and it shows that all estimated variables are stationary at the first difference, that is integrated order one $\{\mathrm{I}(1)\}$, which implies that none of the variables is $\mathrm{I}(0)$. This supports the theoretical basis of the used techniques (Dynamic Least Squares (DOLS), Fully 
Modified Least Squares (FMOLS) and Canonical Cointegrating Regression (CCR)) in the study. For robustness checks, all other relevant tests are also checked for in the analysis, and in particular, the Hasen Instability cointegration test is carried out, and it shows that the variables are cointegrated (see Appendix). Also, in order to know the direction of causality between resource rents and poverty, VECM Granger causality procedure is adopted.

Table 2. Augmented Dickey Fuller (ADF) and Phillips-Perron (PP) unit root test results

\begin{tabular}{|c|c|c|c|c|}
\hline \multirow[t]{2}{*}{ Variable } & \multicolumn{2}{|c|}{ Augmented Dickey Fuller } & \multicolumn{2}{|c|}{ Phillips-Perron } \\
\hline & Level & First difference & Level & First difference \\
\hline Poverty headcount ratio & $-1.11(0)$ & $-5.96(0)^{* * *}$ & -1.09 & $-5.96 * * *$ \\
\hline$G D P$ & $0.40(0)$ & $-4.10(0) * * *$ & 0.26 & $-4.10 * * *$ \\
\hline $\begin{array}{c}\text { Remittances } \\
\text { Democratic ACC }\end{array}$ & $\begin{array}{l}-1.21(0) \\
-1.25(0)\end{array}$ & $\begin{array}{l}-5.94(0) * * * \\
-5.44(0)^{* * *}\end{array}$ & $\begin{array}{l}-1.01 \\
-1.17\end{array}$ & $\begin{array}{l}-6.16 * * * \\
-8.67 * * *\end{array}$ \\
\hline Oil rents & $-0.34(2)$ & $-4.45(3)^{* * *}$ & -1.02 & $-9.18 * * *$ \\
\hline $\begin{array}{c}\text { Non-oil rents } \\
\text { Total Natural resource rents }\end{array}$ & $\begin{array}{l}-1.32(0) \\
-0.16(2)\end{array}$ & $\begin{array}{l}-6.31(0)^{* * *} \\
-5.41(2)^{* * *}\end{array}$ & $\begin{array}{l}-1.32 \\
-1.13\end{array}$ & $\begin{array}{l}-6.31 * * * \\
-7.85 * * *\end{array}$ \\
\hline
\end{tabular}

$* * *$ indicates the level of significance at $1 \%$. Figures in (.) represents lag length selected by AIC criterion. The PP length was selected by Newey-West Band Width.

Following the nature of the analysis, three different models (model (i), (ii) \& (iii)) are estimated, indicating the exclusive examination of the effect of oil rents, non-oil rents and total resource rents on poverty respectively. In table 3 , cointegrating regression results are presented. In model (i) - (iii) and in all the regressions, results indicate that estimated parameters of oil rents, non-oil rents and total resource rents are negative and statistically significant, implying that there is a long-term adverse and significant relationship between resource rents and poverty headcount. These estimates suggest that increased resource rents could lead to a significant reduction in the number of poor people. Although, the natural resource indicators have the same signs, their magnitudes differ. For instance, non-oil rents have a more non-negligible effect on poverty incidence compared to oil and total resource rents in the model. These findings provide a sufficient basis for the view that if the windfall revenue from natural resources is channeled towards pro-poor investments, in the long run, there could be a substantial and sustained decrease in the level of poverty. And as against the undiversified nature of the natural resource sector, non-oil rents have a larger effect on poverty headcount, implying that according considerable attention to non-oil sector other than oil sector might enhance poverty reduction in the country. This study corroborates the previous assertion that the existence of appropriate framework conditions in a country may positively engender significant changes in poverty rate through natural resources (Pineda and Rodriguez, 2010; Bird et al., 2002; Hulme et al., 2001). Regarding democratic accountability, although all the estimated parameters are negative, they are only significant in model (ii) under DOLS, model (ii) \& (iii) (FMOLS) and in model (ii) \& (iii) for CRR; with almost weak significant level. Over time, the variation in the level of significance of this institutional measure is considerable and could offer an elucidation for the spiralling poverty incidence. This empirical evidence reflects the prevailing report that despite the potential positive effect of improved institutions on peoples' welfare, due to pervasive weak institutional frameworks, the quality of institutions has not significantly led to poverty reduction in Nigeria. This exposition also marries up with the study of Odularu (2008); Simon-Oke (2016). On the other hand, both GDP per capita and remittances are significant across models indicating that they are important in explaining the poverty level, which implies that a sustained increase in GDP and in the inflow of remittances are crucial to poverty-alleviating measures. In the work of Adams (2014) and Rewilak, (2017), this evidence is also strongly established.

Turning to Granger causality results in Table 4, findings reveal that the causal direction between natural resource rents and poverty is bi-directional in model (i) \& (iii), whereas it is unidirectional in model (ii) running from non-oil rents to poverty. These suggest that while oil rents, non-oil and total natural resource rents Granger cause poverty, poverty only Granger causes oil and total resource rents, but not non-oil rents. However, except in model (iii) for total resource rents with weak significance, both oil and non-oil rents do not significantly affect poverty headcount in the short run. Based on these findings, it is evidenced that the benefits from natural resource rents often may not contribute to alleviating poverty. This could be linked to public mismanagement of resource windfalls and poor governance (OECD, 2008). 
Table 3. Cointegrating Regression

\begin{tabular}{|c|c|c|c|c|c|c|c|c|c|}
\hline \multirow[t]{2}{*}{ Variable } & \multicolumn{3}{|c|}{ Dynamic Least Squares (DOLS) } & \multicolumn{3}{|c|}{ Fully Modified Least Squares (FMOLS) } & \multicolumn{3}{|c|}{ Canonical Cointegrating Regression (CCR) } \\
\hline & Model (i) & Model (ii) & Model (iii) & Model (i) & Model (ii) & Model (iii) & Model (i) & Model (ii) & Model (iii) \\
\hline Constant & $\begin{array}{c}0.33 * * * \\
{[5.41]}\end{array}$ & $\begin{array}{l}0.21 * * * \\
{[10.47]}\end{array}$ & $\begin{array}{l}0.77 * * * * \\
{[5.34]}\end{array}$ & $\begin{array}{l}0.99 * * * \\
{[12.71]}\end{array}$ & $\begin{array}{c}0.59 * * * \\
{[8.87]}\end{array}$ & $\begin{array}{l}0.36^{* * * *} \\
{[13.45]}\end{array}$ & $\begin{array}{l}0.72 * * * \\
{[11.52]}\end{array}$ & $\begin{array}{c}0.62 * * * \\
{[8.28]}\end{array}$ & $\begin{array}{l}0.39 * * * \\
{[12.13]}\end{array}$ \\
\hline$G D P$ & $\begin{array}{l}-0.38^{*} \\
{[-2.01]}\end{array}$ & $\begin{array}{c}-0.76 * * * \\
{[-6.07]}\end{array}$ & $\begin{array}{c}-0.43 * * \\
{[-2.16]}\end{array}$ & $\begin{array}{c}-0.36^{* * * *} \\
{[-5.07]}\end{array}$ & $\begin{array}{c}-0.44 * * * \\
{[-4.07]}\end{array}$ & $\begin{array}{c}-0.39 * * * \\
{[-5.79]}\end{array}$ & $\begin{array}{c}-0.36^{* * * *} \\
{[-4.58]}\end{array}$ & $\begin{array}{c}-0.43 * * * \\
{[-3.83]}\end{array}$ & $\begin{array}{c}-0.39 * * * \\
{[-5.21]}\end{array}$ \\
\hline Remittances & $\begin{array}{c}0.06 * * * \\
{[4.03]}\end{array}$ & $\begin{array}{c}0.08 * * * \\
{[8.48]}\end{array}$ & $\begin{array}{c}0.06 * * * \\
{[4.03]}\end{array}$ & $\begin{array}{c}0.05 * * * \\
{[7.82]}\end{array}$ & $\begin{array}{c}0.05^{* * *} \\
{[7.62]}\end{array}$ & $\begin{array}{c}0.05^{* * * *} \\
{[8.69]}\end{array}$ & $\begin{array}{c}0.04 * * * * \\
{[8.02]}\end{array}$ & $\begin{array}{c}0.05 * * * \\
{[7.71]}\end{array}$ & $\begin{array}{c}0.05 * * * \\
{[8.92]}\end{array}$ \\
\hline Democratic ACC & $\begin{array}{c}-0.03 \\
{[-0.62]}\end{array}$ & $\begin{array}{l}-0.06^{*} \\
{[-2.21]}\end{array}$ & $\begin{array}{c}-0.03 \\
{[-0.67]}\end{array}$ & $\begin{array}{c}-0.02 \\
{[-1.47]}\end{array}$ & $\begin{array}{l}-0.05 * * \\
{[-2.90]}\end{array}$ & $\begin{array}{l}-0.03 * \\
{[-1.84]}\end{array}$ & $\begin{array}{c}-0.03 \\
{[-1.40]}\end{array}$ & $\begin{array}{c}-0.06 * * \\
{[-2.73]}\end{array}$ & $\begin{array}{l}-0.02 * \\
{[-1.72]}\end{array}$ \\
\hline Oil rents & $\begin{array}{c}-0.13 * * * \\
{[-3.15]}\end{array}$ & & & $\begin{array}{c}-0.09 * * * \\
{[-3.97]}\end{array}$ & & & $\begin{array}{c}-0.10 * * * \\
{[-3.49]}\end{array}$ & & \\
\hline Non-oil rents & & $\begin{array}{c}-0.31 * * * \\
{[-6.36]}\end{array}$ & & & $\begin{array}{c}-0.16 * * * \\
{[-3.12]}\end{array}$ & & & $\begin{array}{l}-0.17 * * \\
{[-2.90]}\end{array}$ & \\
\hline $\begin{array}{c}\text { Total resource } \\
\text { rents }\end{array}$ & & & $\begin{array}{c}-0.15 * * * \\
{[-3.07]}\end{array}$ & & & $\begin{array}{c}-0.12 * * * \\
{[-4.56]}\end{array}$ & & & $\begin{array}{c}-0.12 * * * \\
{[-4.01]}\end{array}$ \\
\hline Normality Test & 0.54 & 0.94 & 0.18 & 0.31 & 0.80 & 0.33 & 0.32 & 0.82 & 0.34 \\
\hline Serial correlation & 0.23 & 0.36 & 0.15 & 0.13 & 0.48 & 0.28 & 0.19 & 0.51 & 0.33 \\
\hline Lag & 2 & 2 & 2 & 2 & 2 & 2 & 2 & 2 & 2 \\
\hline Lead & 1 & 1 & 1 & & & & & & \\
\hline
\end{tabular}

Figures in parentheses are t-values. $(* * *),(* *) \&(*)$ indicate significance at $1 \%, 5 \% \& 10 \%$ respectively. Oil rents, non-oil rents and total resource rents represent model (i), (ii) \& (iii) respectively.

Table 4. Granger causality results based on VECM

\begin{tabular}{|c|c|c|c|c|c|c|c|}
\hline \multirow[t]{2}{*}{ Model } & \multirow[t]{2}{*}{ Lag } & \multicolumn{3}{|c|}{ Natural resource-led poverty } & \multicolumn{3}{|c|}{ Poverty-led natural resources } \\
\hline & & Variable & Short run ${ }^{a}$ & $E C T^{s}$ & Variable & Short run ${ }^{a}$ & $E C T^{s}$ \\
\hline \multirow[t]{4}{*}{ Model (i) } & 1 & Oil rents & 0.47 & $\begin{array}{c}-0.26 * * \\
{[-2.52]}\end{array}$ & Poverty headcount & 0.68 & $\begin{array}{c}-0.30 \text { *** } \\
{[-2.69]}\end{array}$ \\
\hline & & $G D P$ & 0.10 & & $G D P$ & 1.25 & \\
\hline & & Remittances & 0.001 & & Remittances & 1.36 & \\
\hline & & Democratic ACC & 0.20 & & Democratic ACC & $8.08^{* *}$ & \\
\hline \multirow[t]{4}{*}{ Model (ii) } & 1 & Non-oil rents & 0.11 & $\begin{array}{c}-0.16^{* *} \\
{[-1.90]}\end{array}$ & Poverty headcount & $1.65^{*}$ & $\begin{array}{c}-0.05 \\
{[-0.42]}\end{array}$ \\
\hline & & $G D P$ & 0.40 & & $G D P$ & 0.002 & \\
\hline & & Remittances & 0.01 & & Remittances & 0.001 & \\
\hline & & Democratic ACC & 0.19 & & Democratic ACC & 0.02 & \\
\hline \multirow[t]{4}{*}{ Model (iii) } & 1 & Total resource rents & $2.75^{*}$ & $\begin{array}{c}-0.56^{* *} \\
{[-2.88]}\end{array}$ & Poverty headcount & 0.29 & $\begin{array}{c}-0.24 * * \\
{[-2.32]}\end{array}$ \\
\hline & & $G D P$ & 1.05 & & $G D P$ & 1.07 & \\
\hline & & Remittances & $2.24 *$ & & Remittances & 1.30 & \\
\hline & & Democratic ACC & $3.50 * *$ & & Democratic ACC & $11.26 * * *$ & \\
\hline
\end{tabular}

(a ) The Wald statistic is reported. It tests the joint significance of the lagged values of the variables, which follow a $\mathrm{x}^{2}$ distribution. Figures $(\beta)$ in parenthesis represent t-statistic. $(* * *),(* *) \&(*)$ indicate the level of significance at $1 \%$, $5 \%$ and $10 \%$ respectively.

Overall, the findings establish that the efficient, equitable and sustainable use of natural resource rents could help accelerating poverty alleviation process, given the significant nature of the linkage between resources rents and poverty level. The study unfolds the full potential of resource rents for lasting poverty reduction, and that the effect of non-oil rents is more profound in reducing poverty compared with oil rents. In another way, it corroborates the view that, by and large, if the institutional framework is not strengthened, the pro-poor investment strategies and effective management of resource windfalls may be hindered. Hence, improved management of natural resource use is central for ensuring pro-poor results. Evidence from these results mostly attune to the prevailing conditions in subSaharan Africa, and in particular Nigeria. 


\section{$5 \quad$ Concluding remarks}

This study has explored the relationship between resource rents and poverty incidence in Nigeria based on annual time series data between 1984 and 2016. The analysis is done with the use of Dynamic Least Squares (DOLS), Fully Modified Least Squares (FMOLS) and Canonical Cointegrating Regression (CCR), while the causal link is examined using Vector Error Correction Model (VECM) approach. With particular emphasis on long-term effect, the empirical work exclusively focus on the influence of resource windfalls on poverty headcount as against the considerable attention given to the effect of natural resource abundance on economic growth by most previous studies. The analysis specifically covers a broader set of natural resource measures (oil, non-oil and total natural resource rents), and consider their respective effects on poverty level.

The emerging evidence reveals that the elucidation for the co-existence of poverty and a robust state of natural resource rents lies in the processes that enhance effective public management. Although findings establish that there is a longterm adverse and significant relationship between resource rents and poverty headcount, increased resource rents could only lead to a substantial reduction in the number of poor people, if the windfall revenues from natural resources are channeled towards pro-poor investments. Furthermore, compared with oil and total resource rents in the model, nonoil rents have a larger effect on poverty headcount, underscoring that according considerable attention to non-oil sector other than oil sector may stimulate poverty alleviation. There is bi-directional causal relationship between poverty and oil rents and total resource rents, whereas for non-oil rents, it is unidirectional running from non-oil rents to poverty. The study unravels the full potential of resource rents for lasting poverty reduction, and that the effect of non-oil rents is more profound in reducing poverty than oil rents. In conclusion, the study posits that the existence of appropriate framework conditions may positively engender significant changes in poverty rate through natural resources.

Accordingly, in order to ameliorate the spiralling incidence of poverty, adopting effective sustainable resource management measures is critical to enhancing poverty-reducing effect of resource windfalls, as such could promote efficient and equitable distribution of resource rents. By implication, the governance dimensions should play a crucial role in promoting pro-poor development measures. Hence, the study suggests that strengthening the quality of governance for the enhancement of pro-poor investment strategies and effective management of natural resource windfalls is central for alleviating poverty in Nigeria. Thus, improved management of natural resource rents is central for ensuring pro-poor development measures.

\section{References}

Acemoglu, D., (1995). Reward Structures and the Allocation of Talent, European Economic Review, 39: 17-33.

Adams, R. H. (2014). Evaluating the Economic Impact of International Remittances on Developing Countries Using Household Surveys: A literature review. The Journal of Developing Studies, 47(6), 809-828.

Adams, W.M., R., Aveling, and D. Brockington (2004). Biodiversity conservation and the eradication of poverty. Science, 306 (5699), 1146-1149.

Adeyemi, S. L., G.T. Ijaiya and U. Raheem (2009); Determinants of Poverty in Sub-Saharan Africa, African Research Review, Vol 3(2), DOI: 10.4314/afrrev.v3i2.43617.

Akhtar-Schuster, M., R.J. Thomas, L.C. Stringer, P. Chasek, M. Seely, (2011). Improving the enabling environment to combat land degradation: Institutional, financial, legal and science-policy challenges and solutions. Land Degrad. Dev. 22 (2), 299-312.

Akinlo, E. A. and Akinlo, O. O. (2009). Stock Market Development and Economic Growth: Evidence from Seven SubSahara African Countries. Journal of Economics and Business, 61(2), 162-171.

Akinwale, Y.O. (2012). Empirical Analysis of Resource Curse in Nigeria. Int. J. Econ. Manage. Sci. 1(6):19-25.

Ashley C and S. Maxwell S (2001). Rethinking Rural Development. Development Policy Review, 19 (4) 395-425.

Atkinson, G. and K. Hamilton (2003). Savings, Growth and the Resource Curse Hypothesis. World Development, 31(11), 1793-1807.

Auty, R. (2001a). Introduction and Overview' in R. Auty (ed.), Resource Abundance and Economic Development. Oxford: Oxford University Press: 3-16

Badinger, H. and E. Nindl (2014). Globalisation and Corruption, Revisited. The World Economy, 37(10), 1424-1440.

Baland, J.-M. and P. Francois (2000).Rent-seeking and resource booms. Journal of Development Economics, 61(2), 527-542. 
Bird K., D. Hulme, K. Moore and A. Shepherd (2002). Chronic Poverty and Remote Rural Areas. CPRC Working Paper 13. IDPM, University of Manchester, IDD, University of Birmingham.

Brookings Institution (2018). The Start of a New Poverty Narrative. Brookings Institution, USA.

Bulte, E. H., R. Damania, and R. T. Deacon (2005). Resource intensity, institutions, and development. World Development, 33(7), 1029-1044.

Engle, R.F. and Granger, C.W.J. (1987). Cointegration and Error Correction: Representation, Estimation and Testing. Econometrica, 55: 251-276.

Frankel, J. (2010). The Natural Resource Curse: A Survey. NBER Working Paper, No. 15836. Cambridge: National Bureau of Economic Research.

Gylfason, T. (2001). Natural resources, education, and economic development. European Economic Review, 45(4\{6), 847-859.

Hausman, R. and R. Rigabon (2002). An Alternative Interpretation of the 'Resource Curse': Theory and Policy Implications, NBER Working Paper Series, WP 9424, Cambridge: National Bureau of Economic Research.

Hodler, R. (2006). The curse of natural resources in fractionalized countries. European Economic Review, 50(6), 13671386.

Hulme D., K. Moore and A. Shepherd (2001). Chronic Poverty: meanings and analytical frameworks. CPRC Working Paper 2. IDPM, University of Manchester, IDD, University of Birmingham.

Kale, Y. (2012). The Nigeria Poverty Profile 2010 Report. Press Briefing by the Statistician General of the Federation/Chief Executive Officer, National Bureau of Statistics, Dr Yemi Kale at the Conference Room, 5th Floor, NBS Headquarters, Central Business District, Abuja on Monday, 13th February, 2012.

Lane, P. R. and A. Tornell (1996). Power, growth, and the voracity effect. Journal of Economic Growth, 1(2), 213-241.

Leite, C. A. and J. Weidmann (1999). Does Mother Nature Corrupt? Natural Resources, Corruption, and Economic Growth. SSRN Scholarly Paper ID 259928, Social Science Research Network, Rochester, NY.

Manzano, O. and J.S. Scrofina (2013). Resource Revenue Management in Venezuela: A consumption-based poverty reduction strategy. Available at:http://www.revenuewatch.org/sites/default/files/Venezuela_Final.pdf

Mehlum, H., K. Moene and R. Torvik, (2002). Institutions and the Resource Curse, University of Oslo, Department of Economics, Mimeo.

Mehlum, H., K. Moene, and R. Torvik (2006).Institutions and the Resource Curse. The Economic Journal, 116(508), $1-20$.

Mehta, L., M. Leach, P. Newell, I. Scoones; K. Sivaramakrishnan and S. Way (2000). Exploring Understandings of Institutions and Uncertainty: New Directions in Natural Resource Management. IDS Discussion Paper, No. 372, Institute of Development Studies - available online.

Neumayer, E. (2004). Does the "Resource Curse" Hold for Growth in Genuine Income as Well? World Development, 32.10: $1627-40$.

Odularu, G.O. (2008). Crude Oil and the Nigerian Economic Performance. Oil and Gas Business, http://www.ogbus.ru/eng/

OECD (2008). Natural Resources and Pro-Poor Growth: The economics and politics. DAC Guidelines and Reference Series, http://www.oecd.org/dataoecd/56/63/42341879.pdf.

Pineda, J. and F. Rodriguez (2010). Curse or blessing? Natural resources and human development. Human Development Research Paper 2010/04. New York: UNDP.

Raggl, A.K. (2017). Natural Resources, Institutions and Economic Growth: The Case of Nigeria. Policy Research Working Paper 8153.

Rewilak, J. (2017). The role of financial development in poverty reduction. Review of Development Finance, Vol. 7, $169-176$.

Ruijs, A., R. B. Dellink and D.W., Bromley (2008). Economics of poverty, environment and natural-resource use. Rob B. Dellink and Arjan Ruijs (eds.), 3-15.

Sachs, J. D. and A. M.Warner (1995). Natural Resource Abundance and Economic Growth. Working Paper 5398, National Bureau of Economic Research.

Sachs, J. D. and A. M.Warner (2001). The curse of natural resources. European Economic Review, 45(4\{6), 827-838.

Sala-i-Martin, X., and A. Subramanian (2003). Addressing the Natural Resource Curse: An Illustration from Nigeria. Working Paper 9804, National Bureau of Economic Research.

Sala-i-Martin, X., and A. Subramanian (2013). Addressing the Natural Resource Curse: An Illustration from Nigeria. Journal of African Economies, 22(4), 570-615.

Simon-Oke, O.O. (2016). Petroleum resources and Nigeria's poverty profile. Journal of Economics and International Finance, Vol. 8(10), pp. 168-177, DOI: 10.5897/JEIF2016.0796. 
Stock, J.H. and M.W. Watson (1993). A Simple Estimator of Cointegrating Vectors in Higher Order Integrated Systems. Econometrica, Vol. 61, No. 4, July, 783-820.

Sunderlin, W.D., A. Angelsen and B. Belcher, (2005). Livelihoods, forests, and conservation in developing countries: An overview. World Development, 33 (9), 1383-1402.

Torvik, R. (2001). Learning by doing and the Dutch disease. European Economic Review, 45(2), 285-306.

Torvik, R. (2002). Natural resources, rent seeking and welfare. Journal of Development Economics, 67(2), 455-470.

Tripp, R., (2003). The Enabling Environment for Agricultural Technology in Sub-Saharan Africa and the Potential Role of Donors. Overseas Development Institute, London (UK).

World Bank (2018). Human Capital Development Project. The World Bank (Washington, DC 20433).

\section{Appendix}

Model (i)

Cointegration Test - Hansen Parameter Instability

Date: 04/12/19 Time: 19:56

Equation: UNTITLED

Series: LPOVT LOIL LGDP DEMOCRATIC_ACCOUNTABILITY

LREMITANCE

Null hypothesis: Series are cointegrated

Cointegrating equation deterministics: $\mathrm{C}$

White heteroskedasticity-consistent score variance

\begin{tabular}{ccccc}
\hline \hline Lc statistic & $\begin{array}{c}\text { Stochastic } \\
\text { Trends }(\mathrm{m})\end{array}$ & $\begin{array}{c}\text { Deterministic } \\
\text { Trends }(\mathrm{k})\end{array}$ & $\begin{array}{c}\text { Excluded } \\
\text { Trends (p2) }\end{array}$ & Prob. $^{*}$ \\
\hline 0.166667 & 4 & 0 & 0 & $>0.2$ \\
\hline \hline
\end{tabular}

*Hansen (1992b) $L c(m 2=4, k=0) p$-values, where $m 2=m-p 2$ is the number of stochastic trends in the asymptotic distribution.

\section{Model (ii)}

Cointegration Test - Hansen Parameter Instability

Date: 04/12/19 Time: 19:36

Equation: UNTITLED

Series: LPOVT LNONOIL LGDP DEMOCRATIC_ACCOUNTABILITY LREMITANCE

Null hypothesis: Series are cointegrated

Cointegrating equation deterministics: C

\begin{tabular}{ccccc}
\hline \hline Lc statistic & $\begin{array}{c}\text { Stochastic } \\
\text { Trends }(\mathrm{m})\end{array}$ & $\begin{array}{c}\text { Deterministic } \\
\text { Trends }(\mathrm{k})\end{array}$ & $\begin{array}{c}\text { Excluded } \\
\text { Trends }(\mathrm{p} 2)\end{array}$ & Prob. $^{*}$ \\
\hline 0.621400 & 4 & 0 & 0 & $>0.2$ \\
\hline \hline
\end{tabular}

*Hansen (1992b) $L c(m 2=4, k=0) p$-values, where $m 2=m-p 2$ is the number of stochastic trends in the asymptotic distribution. 


\section{Model (iii)}

Cointegration Test - Hansen Parameter Instability

Date: 04/12/19 Time: 19:48

Equation: UNTITLED

Series: LPOVT LRESOURCE LGDP DEMOCRATIC_ACCOUNTABILITY LREMITANCE

Null hypothesis: Series are cointegrated

Cointegrating equation deterministics: C

\begin{tabular}{ccccc}
\hline \hline Lc statistic & $\begin{array}{c}\text { Stochastic } \\
\text { Trends }(\mathrm{m})\end{array}$ & $\begin{array}{c}\text { Deterministic } \\
\text { Trends }(\mathrm{k})\end{array}$ & $\begin{array}{c}\text { Excluded } \\
\text { Trends (p2) }\end{array}$ & Prob. $^{*}$ \\
\hline 0.367559 & 4 & 0 & 0 & $>0.2$ \\
\hline \hline
\end{tabular}

*Hansen (1992b) $\mathrm{Lc}(\mathrm{m} 2=4, \mathrm{k}=0) \mathrm{p}$-values, where $\mathrm{m} 2=\mathrm{m}-\mathrm{p} 2$ is the number of stochastic trends in the asymptotic distribution 